\title{
Genotoxic and biochemical responses in caged eel (Anguilla anguilla L.) after short-term exposure to harbour waters
}

\author{
V.L. Maria, A.C. Correia, M.A. Santos* \\ Department of Biology, University of Aveiro, 3810-193 Aveiro, Portugal \\ Received 23 October 2002; accepted 24 February 2003
}

\begin{abstract}
European eel (Anguilla anguilla L.) were caged and exposed in situ for 8 and $48 \mathrm{~h}$ to the Aveiro offward fishing harbour water (HW) and to clean seawater under laboratory conditions (Control). Eel liver biotransformation (Phase I) was measured as ethoxyresorufin- $O$-deethylase (EROD) activity, cytochrome $P 450$ ( $P 450)$ and glutathione $S$-transferase (GST) activity (Phase II). Genotoxic responses were determined as blood, liver and kidney DNA strand breaks as well as erythrocytic nuclear abnormalities (ENAs).

HW failed to significant increase liver EROD, GST activities and ENA frequency. Nevertheless, $P 450$ content was significantly increased after 8 and $48 \mathrm{~h}$ exposure. Genotoxicity measured as DNA integrity decrease was found in blood after 8 and 48 h exposure to HW, whereas in liver and kidney, it was observed after $48 \mathrm{~h}$ exposure to HW.

Blood, kidney and liver genotoxicity may be due to the presence of polycyclic aromatic hydrocarbons (PAHs) which are genotoxic compounds and the main HW organic contaminants.
\end{abstract}

(C) 2003 Elsevier Science Ltd. All rights reserved.

Keywords: Genotoxicity; DNA strand breaks; ENAs; EROD; P450; Anguilla anguilla L.

\section{Introduction}

The impact of industrial effluents on marine ecosystems is complex, because exposure to its contaminants, directly or indirectly, impairs the organisms via induced altered metabolism and leading eventually to a decreased viability (Everaarts et al., 1998). Polycyclic aromatic hydrocarbon (PAH) contamination, resulting from oil tanker accidents, major spillage, industry and municipal waste discharges (Kennish, 1992) are among the different types of pollutants normally attributable to anthropogenic activities. Among mixed-function oxidases (MFOs), liver ethoxyresorufin- $O$-deethylase (EROD) activity, a Phase I biotransformation enzyme, has been extensively studied and adopted as a valuable indicator of water PAH and other organic xenobiotic contamination (Stegeman and Lech, 1991; Addison et al., 1994; Pacheco and Santos, 1998, 2001). According to Tuvikene et al. (1999), responses such as catalytic activities associated to cytochrome P450 (P450) seem to be inhibited, whereas glutathione $S$-transferase (GST) induction is the only meas-

\footnotetext{
* Corresponding author.

E-mail addresses: vmaria@bio.ua.pt (V.L. Maria), acorreia@bio.ua.pt (A.C. Correia), monteiro@bio.ua.pt (M.A. Santos).
}

urable response. Fish P4501A induction associated with DNA damage studies in fish exposed to PAH xenobiotics, proved to be also a powerful way of monitoring aquatic pollution (Goksøyr and Förlin, 1992; De Flora et al., 1993).

Several environmental interactions can alter the genotoxic potential of complex industrial effluents (Claxton et al., 1998; Maria et al., 2002c). The genotoxicity of industrial pollutants related to effluent complex mixtures, such as the harbour waters (HW), needs to be monitored (Zoll-Moreaux and Ferrier, 1999). Therefore, DNA damage measured as adduct formation (Stein et al., 1990; El Adlouni et al., 1995) and strand breaks (Everaarts and Sarkar, 1996; Everaarts et al., 1998) were previously presented as useful for the monitoring genotoxicity in the environment (Shugart et al., 1992). The assessment of environmental contamination has been carried out using caged fish exposed in situ to polluted waters (Rice et al., 1994; Pacheco and Santos, 2001).

Anguilla anguilla $\mathrm{L}$. is a representative species of the Aveiro Lagoon that despite its description as a bottom dwelling fish, can move along the entire water column thus being a versatile indicator species with a high economic value, easy to capture and to maintain in laboratory (Costa et al., 1992). Previous research concerning this species physiological and genotoxic responses to the Aveiro 
Lagoon industrial effluents and their isolated contaminants, measured as blood plasma cortisol, glucose and lactate, liver alanine amino transferase (ALT) and EROD activity and erythrocytic nuclear abnormalities (ENAs) (Santos et al., 1990; Pacheco and Santos, 1998, 1999, 2001), proved its sensitivity as well as its resistance to those adverse conditions.

In Portugal, Aveiro Lagoon, the long-distance harbour presents a PAH contamination ranging between 0.0075 and $0.0086 \mathrm{ng} \mathrm{ml}^{-1}$ (Pacheco and Santos, 2001) due to intense industrial sewage harbour activity. In this perspective, the present research work concerns a field study with caged eels exposed in situ to harbour waters, during 8 and $48 \mathrm{~h}$, to relate genotoxic responses such as blood, liver and kidney DNA strand breaks as well as ENAs with biotransformation measured as liver EROD, GST activity and P450 content. ALT activity was also determined for the indication of liver hepatocyte plasma membrane disruption (Santos et al., 1990; Pacheco and Santos, 1999).

\section{Materials and methods}

\subsection{Chemicals}

All chemicals were of analytical grade, obtained from Sigma (USA), Roche (Germany) and E. Merck-Darmstadt (Germany).

\subsection{Fish}

European eel (A. anguilla L.), with an average weight of $50 \mathrm{~g}$ (silver eel), were collected from the Aveiro LagoonMurtosa (Portugal). The eels were transported in anoxia, acclimatized to laboratory conditions in aerated, recirculated, filtered and artificial seawater in 80-1 aquaria for 1 week, at $20{ }^{\circ} \mathrm{C}$ under a natural photoperiod [light/dark (hours) $=12]$. Fish were not fed during recovery. The 1week recovery period after capture revealed that all biomarkers are according to control levels found in reference sites (Santos and Pacheco, 1996).

\subsection{Biochemical analyses}

\subsubsection{Liver EROD assay}

Microsomes were obtained according to the methods of Lange et al. (1992) and Monod and Vindimian (1991) as adapted by Pacheco and Santos (1998). Liver EROD activity was measured as described by Burke and Mayer (1974). Results were expressed as $\mathrm{pmol} / \mathrm{min} / \mathrm{mg}$ of microsomal protein.

\subsubsection{P450 content}

P450 content was quantified by measuring the 490 - to 450-nm absorbance spectrum as described by Hermens et al. (1990).

\subsubsection{GST assay}

Liver GST activity was determined as described in Habig et al. (1974) and Lemaire et al. (1996), with 1-chloro-2,4dinitro-benzene (CDNB) as substrate. The assay prepared in the cuvette was carried out in a 2-ml mixture of $0.2 \mathrm{M}$ phosphate buffer ( $\mathrm{pH} 7.4$ ), $0.2 \mathrm{mM} \mathrm{CDNB}$ and $0.2 \mathrm{mM}$ GSH. The reaction was initiated by sample addition. The increase in absorbance at $340 \mathrm{~nm}$ was recorded at $25^{\circ} \mathrm{C}$ for 3 min.

\subsubsection{Liver ALT assay}

ALT activity was measured according to Reitman and Frankel (1957) in the supernatant resulting from liver microsomal isolation (Santos et al., 1990; Pacheco and Santos, 1999).

\subsubsection{Protein measurement}

Microsomal protein content and supernatant protein concentration were determined according to the Biuret method (Gornall et al., 1949), using bovine serum albumin (E. Merck-Darmstadt) as a standard.

\subsection{Genotoxicity responses}

Genotoxicity was tested using the ENAs and the DNA alkaline unwinding assay. ENA test was carried out in eel's mature erythrocytes, according to the procedures of Schmid (1976), Carrasco et al. (1990) and Smith (1990) as adapted by Pacheco and Santos (1996). Each group final result was presented as the mean value (\%o) of the sums for all the individual lesions observed and scored in 1000 cells per fish blood smear. Blood and liver DNA integrity measurements (\%) were performed according to Rao et al. (1996), with minor modifications, where liver and blood DNA was extracted from liver and blood tissues by Genomic DNA Purification Kit, Fermentas, USA. Data from blood and liver DNA alkaline unwinding technique were expressed as $F$ value (\%) double-stranded DNA over double stranded DNA plus single-stranded DNA.

\subsubsection{Statistical analysis}

The results are expressed as mean \pm standard error (S.E.) and statistical analysis was performed using a two-tailed Student's $t$ test (Bailey, 1959).

\subsection{Experimental protocols}

Eels were not fed during the exposure period to harbour water and to clean water (control group). Adult eels were exposed during 8 and $48 \mathrm{~h}$, in cages, to the following conditions:

1- The eels were exposed during high tide to the Aveiro harbour waters (HW) - offward fishing Port (Aveiro estuary). Fish were transported in cages from laboratory to the harbour location in anoxia (30 $\mathrm{min})$, and plunged 
near the sediment. The total volume of each net cage was $80 \mathrm{dm}^{3}$. The experiment was carried out in October, at approximately $21{ }^{\circ} \mathrm{C}$ water temperature.

2 - Similarly to the harbour condition, control eels (C) were kept in net cages (volume $=80 \mathrm{dm}^{3}$ ), into aerated, filtered and artificial seawater at $20{ }^{\circ} \mathrm{C}$ under laboratory conditions (natural photoperiod), and submitted to the equivalent previous anoxia period $(30 \mathrm{~min})$.

Each exposure condition was carried out using test groups of five eels each $(n=5)$. Fish were killed by decapitation; their blood, kidney and liver were sampled. Blood smears were prepared for ENA assay. Each liver was divided into two halves where one was immediately frozen in liquid nitrogen and stored at $-20{ }^{\circ} \mathrm{C}$ for later liver EROD, P450, GST and ALT determination, while the other half was placed in TNES-urea $(8 \mathrm{M})$ buffer with proteinase $\mathrm{K}$ solution (final concentration, $0.8 \mathrm{mg} / \mathrm{ml}$ ) for DNA isolation procedure (Genomic DNA Purification Kit). Fresh blood samples, after centrifugation and plasma separation, were stored overnight at $4{ }^{\circ} \mathrm{C}$ with TNES-urea $(8 \mathrm{M})$ buffer for DNA isolation. Blood, liver and kidney DNA extraction was carried out for the DNA strand breaks assay.

\section{Results and discussion}

\subsection{Genotoxicity responses}

A significant decrease in $A$. anguilla $\mathrm{L}$. blood DNA integrity was found after $8(p<.02)$ and $48(p<.05) \mathrm{h}$ exposure to HW (Fig. 1a). However, a significant decrease in liver $(p<.05)$ and kidney $(p<.01)$ DNA integrity was only observed at $48 \mathrm{~h}$ exposure to HW, compared to their controls (Fig. 1b,c). A significant decrease in the eel's liver DNA integrity after $48 \mathrm{~h}(p<.01)$ compared to $8 \mathrm{~h}$ exposure to HW was also observed (Fig. 1b). The highest DNA integrity decrease was found in blood (16.5\%), followed by kidney (16.3\%) and liver (15\%), after $48 \mathrm{~h}$ exposure to HW (Fig. 1a-c).

Despite the absence of significant ENAs frequency differences, between control and exposed eels, the results exhibit an increased ENA tendency after $48 \mathrm{~h}$ exposure to HW (Fig. 2).

Harbour waters contain (Pacheco and Santos, 2001) various progenotoxic PAHs that may be environmentally biotransformed into reactive genotoxic compounds leading to genotoxic effects in aquatic species (James and Kleinow, 1994; Maria et al., 2002a).

The eels' liver S9 capacity of converting a progenotoxic substance, such as $\mathrm{BaP}$, into a genotoxic compound with mutagenic effects, was previously demonstrated by the Ames test (Maria et al., 2002b).

An early blood DNA strand breaks increase after $8 \mathrm{~h}$ compared to a delayed liver and kidney increase after $48 \mathrm{~h}$ exposure to $\mathrm{HW}$ in caged $A$. anguilla $\mathrm{L}$., is probably due to
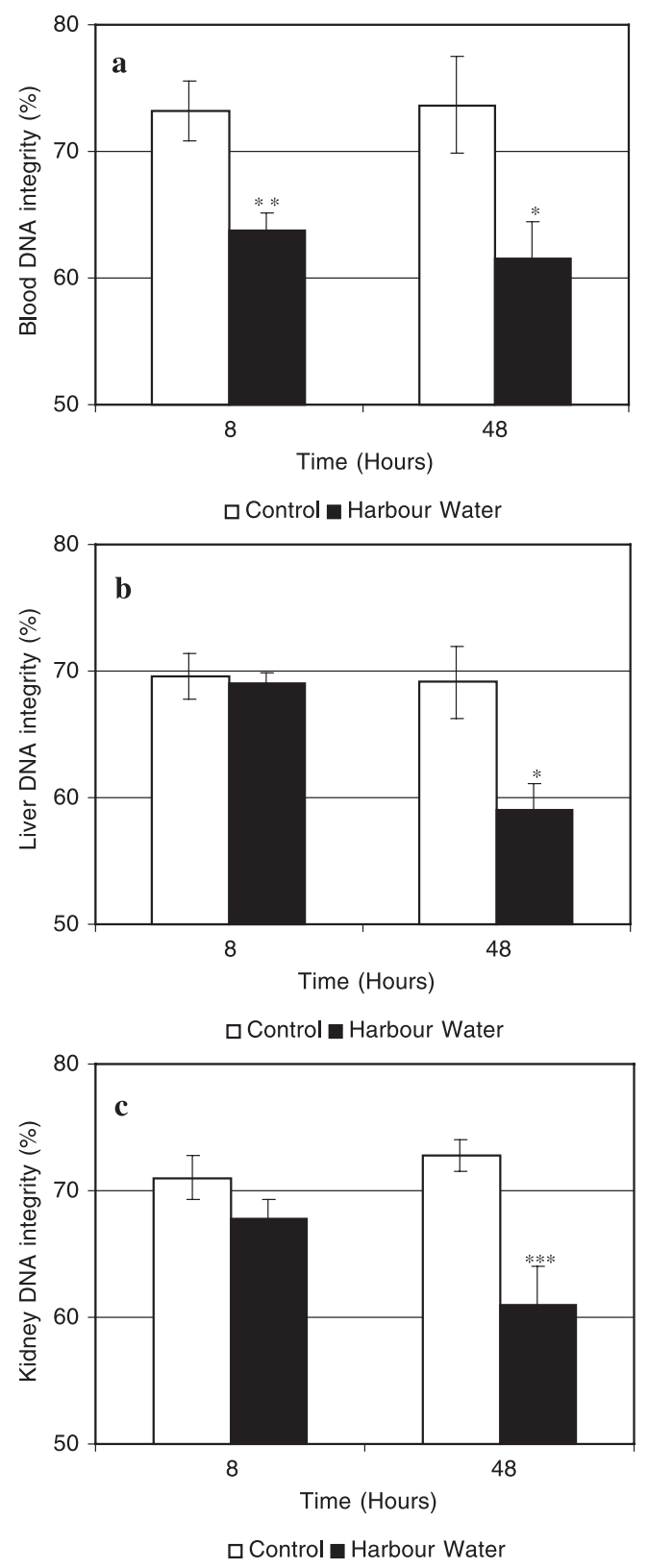

Fig. 1. Blood (a), liver (b) and kidney (c) DNA integrity (\%) in adult eel (A. anguilla L.) exposed to harbour waters in field at 8 and $48 \mathrm{~h}$. Values represent mean \pm S.E. Differences from control: ${ }^{*} p<.05$; ${ }^{* *} p<.02$; $* * * p<.01$.

the direct action of genotoxic and progenotoxic compounds such as PAHs/PAH metabolites present in the HW, and consequent blood DNA damage. Maria et al. (2002a) previously found that the eels' blood DNA integrity decreased after $8 \mathrm{~h}$ exposure to 0.9 and $2.7 \mu \mathrm{M} \mathrm{BaP}$, suggesting the presence of PAH progenotoxic equivalent concentrations in the HW, where our experimental animals were exposed.

According to Maria et al. (2002c), the eel's DNA blood damage measured as strand breaks was also observed after 8,16 and $24 \mathrm{~h}$ exposure to $50 \%$ diluted pulp mill effluent as well as at 16 and $24 \mathrm{~h}$ exposure to $25 \%$ diluted pulp mill 


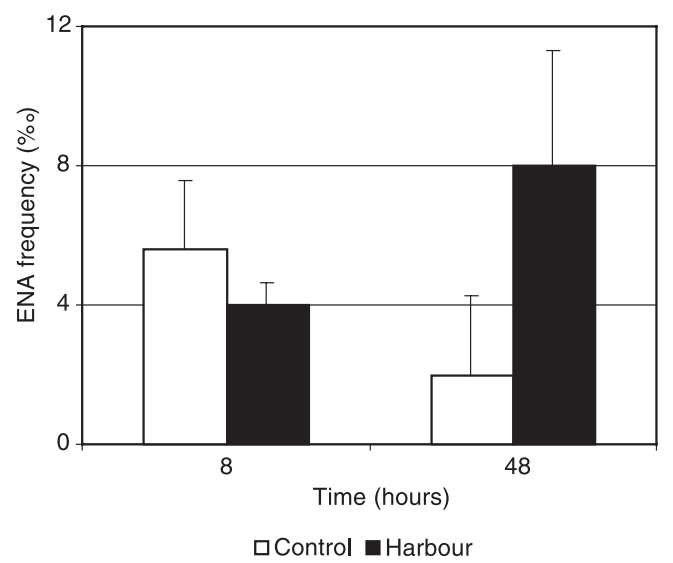

Fig. 2. ENA frequency ( $\%$ ) in adult eel (A. anguilla L.) exposed to harbour waters in field at 8 and $48 \mathrm{~h}$. Values represent mean \pm S.E. No statistical differences from control.

effluent, demonstrating once again that the dilution of a complex effluent results in a delayed DNA-damaging effect. Other authors such as Devaux et al. (1998) also observed that chub (Leuciscus cephalus) caught in Rhône River close to an industrial area presented an increased DNA damage in their erythrocytes.

PAH reactive intermediates have the potential to interact with any nucleophilic sites within the cell, including those on proteins, DNA and induce a genotoxic response. It should be noted that the formation of reactive intermediates might not lead to cellular toxicity if there is a balance between the rates of their formation and detoxification (Shugart, 1996). A most efficient phase II detoxification process may be responsible for a delayed liver and kidney DNA integrity decrease at $48 \mathrm{~h}$ because the experimental results of Ahmad et al. (2002) demonstrated an increased liver GSH content after $8 \mathrm{~h}$ exposure and further liver lipid peroxidation (LPO) after $48 \mathrm{~h}$ exposure to HW concomitantly with a GSH liver content decrease. Despite blood DNA strand breaks increase after 8 and $48 \mathrm{~h}$ exposure to $\mathrm{HW}$, an ENA frequency increase was not found. However, Maria et al. (2002c) demonstrated A. anguilla L. ENA increase after 8, 16 and $24 \mathrm{~h}$ exposure to pulp mill effluent in laboratory conditions. ENA frequency absence in HWexposed eels may be due either an efficient removal by the spleen and/or an inhibition in erythrocytic production during this exposure period. A slight non-significant elevation of ENA frequency noticed after $48 \mathrm{~h}$ exposure suggests either the necessity of an extended exposure length or/and the use of different HW dilutions.

According to White (2002), the absence of information about the behaviour of toxic substances in complex mixtures is often avoided by assuming that the toxicity of a mixture is simply the sum of the expected effects from each mixture component, that is, no synergistic or antagonistic interactions.

In previous field studies with caged A. anguilla L., neither significant liver EROD activity nor ENA increase was observed after 1 and 3 days of environmental exposure to HW (Pacheco and Santos, 2001). However, laboratory studies with the same species exposed for 1 day to low tide harbour water (LTHW) demonstrated the presence of liver EROD inducers, whereas after 3 days of exposure to high tide harbour water (HTHW), the presence of ENA inducers was revealed (Pacheco and Santos, 2001). According to Shugart (1996) animal aquatic species exposed either to natural field or laboratory conditions seem to respond differently. Therefore, some difficulties on the field data interpretation may arise, as fish may be affected by the influence of environmental factors such as air and water temperature, water flow and currents on the relative amounts of hydrocarbons in the water (Neff, 1990; Pacheco and Santos, 2001). However, the ENA significant increase found by Gravato et al. (2000) in the juvenile sea bass, after $6 \mathrm{~h}$ exposure to HT and LT HW under laboratory conditions, also confirmed the presence of genotoxic compounds in the HW and seems to be related with species differences.

\subsection{Biotransformation responses}

Though not statistically different from control groups, liver EROD activity slightly increased in eels after $8 \mathrm{~h}$ exposure to HW (Table 1). However, liver $P 450$ content significantly increased at $8(p<.01)$ and $48(p<.01) \mathrm{h}$ exposure, compared to control levels (Table 1).

Previous results, concerning liver $P 450$ content increase after 8 and $48 \mathrm{~h}$ exposure to HW despite no EROD activity increase may be due to their high PAH concentration. According to Gooch et al. (1989) and Haasch et al. (1993), high PAH concentrations (BaP) and PAH-like compounds (BNF) can also inhibit liver EROD catalytic activity. This was also supported by Gravato et al. (2000) who demonstrated an increased liver $P 450$ content in sea bass (Dicentrarchus labrax) after $6 \mathrm{~h}$ to HTHW, whereas no significant liver EROD activity increase was found.

Table 1

Liver EROD activity ( $\mathrm{pmol} / \mathrm{min} / \mathrm{mg}$ protein), $P 450$ content (nmol/mg/ protein), GST activity ( $\mathrm{nmol} / \mathrm{min} / \mathrm{mg}$ protein) and ALT activity (U/g) in adult eel ( $A$. anguilla L.) exposed to harbour waters in field at 8 and $48 \mathrm{~h}$

\begin{tabular}{|c|c|c|c|}
\hline Parameters & $\begin{array}{l}\text { Time } \\
\text { (h) }\end{array}$ & Control & Harbour waters \\
\hline \multirow{2}{*}{$\begin{array}{l}\text { Liver EROD activity } \\
\qquad(\mathrm{pmol} / \mathrm{min} / \mathrm{mg} \text { protein })\end{array}$} & 8 & $1.076 \pm 0.102$ & $1.850 \pm 0.485$ \\
\hline & 48 & $0.750 \pm 0.187$ & $0.996 \pm 0.344$ \\
\hline \multirow{2}{*}{$\begin{array}{l}P 450 \text { content } \\
\quad(\mathrm{nmol} / \mathrm{mg} \text { protein })\end{array}$} & 8 & $0.154 \pm 0.0211$ & $0.384^{\mathrm{a}} \pm 0.0623$ \\
\hline & 48 & $0.197 \pm 0.00252$ & $0.261^{\mathrm{a}} \pm 0.0157$ \\
\hline \multirow{2}{*}{$\begin{array}{l}\text { Liver GST activity } \\
\qquad(\mathrm{nmol} / \mathrm{min} / \mathrm{mg} \text { protein })\end{array}$} & 8 & $71.791 \pm 3.836$ & $100.951 \pm 12.305$ \\
\hline & 48 & $71.803 \pm 3.886$ & $83.202 \pm 3.248$ \\
\hline \multirow[t]{2}{*}{ Liver ALT activity (U/g) } & 8 & $1.678 \pm 0.0605$ & $1.669 \pm 0.130$ \\
\hline & 48 & $1.413 \pm 0.1115$ & $1.443 \pm 0.0655$ \\
\hline
\end{tabular}

Values represent mean \pm S.E. ${ }^{\mathrm{b}}$

${ }^{\text {a }}$ Differences from control: $* * * p<.01$

${ }^{\mathrm{b}}$ Each exposure condition was carried out using test groups of five eels each $(n=5)$. 
Several inducers of CYP1A synthesis can also inhibit MFO catalytic activity [EROD or aryl hydrocarbon hydroxylase (AHH)] (Stegeman and Hahn, 1994). According to Goksøyr et al. (1991), elevated P450 1A protein was found in fish from one site containing elevated contaminant despite no EROD activity increase. Sea bass liver microsomal EROD activity was also inhibited in vitro by low $\mathrm{BNF}(0.001 \mu \mathrm{M})$ and $\mathrm{BaP}(0.01 \mu \mathrm{M})$ concentrations. Moreover, $\mathrm{BNF}$ and $\mathrm{BaP}$ doses ranging from 0.1 to $2.7 \mu \mathrm{M}$ inhibited at least $85 \%$ of liver EROD activity (Gravato and Santos, 2002). However, Rice et al. (1994) found a significant relationship between caged speckled sanddabs MFO responses and sediment hydrocarbon concentrations in a field study to monitor the potential hydrocarbon impact at Moss Landing. In the present field studies with caged $A$. anguilla L., HW exposure and liver EROD activity increased failure, suggesting either inhibition or inactivation mechanisms by the harbour water complex mixture which include elevated PAH concentrations (Pacheco and Santos, 2001; Gravato et al., 2000) and significant levels of heavy metals (Hall et al., 1988).

In vitro studies concerning previously exposed $D$. labrax to organic xenobiotics such as BNF (Viarengo et al., 1997; Oliveira et al., 2002) have demonstrated liver microsomal EROD activity inhibition by heavy metals. Other compounds, such as tributyltin (TBT) has been recognised as potent in vitro liver microsomal EROD activity inhibitor in fish (Fent and Stegeman, 1993) having been found in the Aveiro Lagoon water and sediment (Barroso et al., 1998). Liver GST activity was not altered for any exposure condition (Table 1), which suggests a failure on Phase II conjugation process.

\subsection{Liver damage}

Liver ALT activity results were not altered after any HW exposure condition (Table 1) demonstrating that there was no liver hepatocyte plasma membrane disruption after $48 \mathrm{~h}$ exposure despite liver LPO increase (Ahmad et al., 2002, personal communication). The equivalent result was also observed by Pacheco and Santos (2001) in eels after 1 and 3 days of exposure to high tide HW and low tide HW. Gravato et al. (2000) also demonstrated no significant liver ALT activity alteration in sea bass (D. labrax) after $6 \mathrm{~h}$ exposure to HTHW and LTHW.

\section{Conclusion}

This study reveals that there are genotoxic and/or progenotoxic compounds among harbour water contaminants, which are able to induce early genotoxicity as DNA strand breaks in eel's blood cells and a delayed genotoxicity in liver and kidney. In this field short-term exposure to HW, a significant ENA response was not observed. The genotoxicity increase in liver and kidney at $48 \mathrm{~h}$ exposure to $\mathrm{HW}$ is probably due to a failure in the detoxification process where some of the unconjugated-reactive HW metabolites may be responsible for DNA damage. Liver P450 content increase in eels despite the failure in liver EROD activity induction, is probably due to a complex mixture of high PAHs concentrations in harbour water contamination, which is able to induce the cytochrome synthesis, preventing, however, the liver EROD activity increase.

To avoid misleading experimental results concerning the failure in liver EROD and ENA induction in monitoring field studies by effluent complex mixture, further studies should be complemented by shortening the interval between 8 and $48 \mathrm{~h}$ as well as prolonging it over $48 \mathrm{~h}$ exposure.

\section{Acknowledgements}

The authors express their appreciation for the financial support provided by the program Praxis XXI through contract PCNA/C/BIA/175-96 and grant BD/18254/98 and by the Aveiro University Research Institute.

\section{References}

Addison RF, Willis DE, Zinck ME. Liver microsomal monooxygenase induction in winter flounder (Pseudopleuronectes americanus) from a gradient of sediment PAH concentrations at Sidney Harbour, Nova Scotia. Mar Environ Res 1994;37:283-96.

Ahmad I, Pacheco M, Santos MA. Enzymatic and non-enzymatic antioxidants as an adaptation to phagocytes-induced tissue specific damage in Anguilla anguilla L. to in situ harbour water exposure. Personal communication 2002.

Bailey NJ. Statistical methods in biology. London: English Universities Press; 1959.

Barroso C, Moreira MH, Gibbs P. Contaminação da Ria de Aveiro por TBT e o seu efeito em populações locais de neograstrópodes. Presented in IX seminário Ibérico de Química Marinha, 16-18 April; Aveiro, Portugal; 1998.

Burke MD, Mayer RT. Ethoxyresorufin: direct fluorimetric assay of a microsomal-O-deethylation, which is preferentially inducible by 3 methylcholanthrene. Drugs Metab Dispos 1974;2:583-8.

Carrasco KR, Tilbury KL, Meyrs MS. Assessment of the piscine micronuclei test as an in situ biological indicator of chemical contaminant effects. Can J Fish Aquat Sci 1990;47:2123-36.

Claxton LD, Houk V, Hughes TJ. Genotoxicity of industrial wastes and effluents. Mutat Res 1998;410:237-43.

Costa JL, Assis CA, Almeida PR, Moreira FM, e Costa MJ. On the food of the European eel, Anguilla anguilla (L.), in the upper zone of the Tagus estuary, Portugal. J Fish Biol 1992;41:841-50.

De Flora S, Vigano L, D’Agostini F, Camoirano A, Bagnasco M, Bennicelli $\mathrm{C}$, et al. Multiple genotoxicity biomarkers in fish exposed in situ to polluted river water. Mutat Res 1993;319:167-77.

Devaux A, Flammarion P, Bernardon V, Garric J, Monod G. Monitoring of the chemical pollution of the River Rhône through measurement of DNA damage and cytochrome P4501A1 induction in chub (Leuciscus cephalus). Mar Environ Res 1998;46(1-5):257-62.

El Adlouni C, Tremblay J, Walsh P, Lagueux J, Bureau J, Lalibert D, et al. Comparative study of DNA adducts levels in white sucker fish (Catostomus commersini) from the basin of the St. Lawrence River (Canada). Mol Biochem 1995;148(2):133-8.

Everaarts JM, Sarkar A. DNA damage as a biomarker of marine pollution: 
strand breaks in seastars (Asterias rubens) from the North Sea. Water Sci Technol 1996;34(7-8):157-62.

Everaarts JM, Den Besten PJ, Hillebrand MThJ, Halbrook RS, Shugart LR. DNA strand breaks, cytochrome $P 450$-dependent monooxygenase system activity and levels of chlorinated biphenyl congeners in the pyloric caeca of the Seastar (Asterias rubens) from the North Sea. Toxicology 1998;7:69-79.

Fent K, Stegeman JJ. Effects of tributyltin in vivo on hepatic cytochrome $P 450$ forms in marine fish. Aquat Toxicol 1993;24:219-40.

Goksøyr A, Förlin L. The cytochrome $P 450$ in fish, aquatic toxicology and environmental monitoring. Aquat Toxicol 1992;22:287-312.

Goksøyr A, Husoy AM, Larsen HE, Klungsoyr J, Wilhelmesen S, Maage A, et al. Environmental contaminants and biochemical responses in flatfish from the Hvaler Archipelago in Norway. Arch Environ Contam Toxicol 1991;21(4):486-96.

Gooch JW, Elskus AA, Kloepper-Sams PJ, Hahn ME, Stegeman JJ. Effects of ortho and non-ortho substituted polychlorinated biphenyl congeners on the hepatic monooxygenases system in scup (Stenotomus chrysops). Toxicol Appl Pharmacol 1989;98:422.

Gornall AC, Bardawill CJ, David MM. Determination of serum proteins by means of the biuret reaction. J Biol Chem 1949;177(2):751-66.

Gravato C, Santos MA. In vitro liver EROD activity inhibition by Ahreceptor agonists. Fresenius Environ Bull 2002;11(7):342-6.

Gravato C, Santos MA, Magalhães I. Juvenile Dicentrarchus labrax L. biochemical and genotoxic responses after shot-term exposure to $\beta$ naphthoflavone and contaminated harbour waters. Fresenius Environ Bull 2000;9:269-74.

Haasch ML, Quardokus EM, Sutherland LA, Goodrich MS, Lech JJ. Hepatic CYP1A1 induction in rainbow trout by continuous follow-trough exposure to $\beta$-naphthoflavone. Fundam Appl Toxicol 1993;20:72-82.

Habig WH, Pabst MJ, Jokoby WB. Glutathione $S$-transferase. The first enzymatic step in mercapturic acid formation. J Biol Chem 1974;249: $7130-9$.

Hall A, Duarte AC, Caldeira MTM, Lucas MFB. Sources and sinks of mercury in the coastal lagoon of Aveiro. Sci Total Environ 1988;64: $75-87$.

Hermens JLP, Bradbury SP, Broderius SJ. Influence of cytochrome P450 mixed-function oxidase induction on the acute toxicity to Rainbow trout (Salmo gairdneri) of primary aromatic amines. Ecotoxicol Environ Saf 1990;20:156-66.

James MO, Kleinow KM. In: Malins DC, Ostrander GK, editors. Trophic transfer of chemicals in the aquatic environment. Aquatic toxicologymolecular. Biochemical and cellular perspectives. Boca Raton: Lewis Publishers, CRC Press; 1994. p. 1-35

Kennish MJ. Ecology of estuaries: anthropogenic effects. Boca Raton (FL): CRC Press; 1992.

Lange U, Danishchewski D, Siebers D. Regional variability and sexual differences in ethoxyresorufin- $O$-deethylase activities and cytochrome $P 450$ concentration in the liver of mature dab (Limanda limanda L.) in German Bight. Variability of EROD and cytochrome P450 in North Sea dab. Weinheim: VCH; 1992.

Lemaire P, Förlin L, Livingstone DR. Responses of hepatic biotransformation and antioxidant enzymes to CYP1A-inducers (3-methylcholanthrene, $\beta$-naphthoflavone) in sea bass (Dicentrarchus labrax), dab (Limanda limanda) and rainbow trout (Oncorhynchus mykiss). Aquat Toxicol 1996;36:141-60.

Maria VL, Correia AC, Santos MA. Anguilla anguilla L. biochemical and genotoxic responses to benzo(a)pyrene. Ecotoxicol Environ Saf 2002a; 53:86-92.

Maria VL, Correia AC, Santos MA. Benzo(a)pyrene and $\beta$-naphthoflavone mutagenic activation by European eel (Anguilla anguilla L.) S9 liver fraction. Ecotoxicol Environ Saf 2002b;53:81-5.

Maria VL, Correia AC, Santos MA. Genotoxic and hepatic biotransformation responses induced by the overflow of pulp mill and secondary treated effluents on Anguilla anguilla L. Ecotoxicol Environ Saf [in press].

Monod G, Vindimian E. Effect of storage conditions and subcellular frac- tionation of fish and cytochrome P450-dependent enzymatic activities used for the monitoring of water pollution. Water Res 1991;25(2): $173-7$.

Neff JM. Composition and fate of petroleum and spill-treating agents in the marine environment. In: Geraci JR, St Aubin DJ, editors. Sea mammals and oil: confronting risks. London: Academic Press; 1990. p. 1-32.

Oliveira M, Santos MA, Pacheco M. The glutathione protective effects on liver microsomal EROD activity inhibition induced by heavy metals in Dicentrarchus labrax L. Personal communication 2002.

Pacheco M, Santos MA. Induction of micronuclei and nuclear abnormalities in the erythrocytes of Anguilla anguilla L. exposed either to cyclophosphamide or to bleached kraft pulp mill effluent. Fresenius Environ Bull 1996;5:746-51.

Pacheco M, Santos MA. Anguilla anguilla L. liver EROD and erythrocytic nuclear abnormalities induction by cyclophosphamide and PAHs. Ecotoxicol Environ Saf 1998;40:71-6.

Pacheco M, Santos MA. Biochemical and genetic responses of adult eel (Anguilla anguilla L.) to resin acids and pulp mill effluent: laboratory and field experiments. Ecotoxicol Environ Saf 1999;42:81-93.

Pacheco M, Santos MA. Biotransformation, endocrine, and genetic responses of Anguilla anguilla L. to petroleum distillate products and environmentally contaminated waters. Ecotoxicol Environ Saf 2001; 49:64-75.

Rao SS, Neheli TA, Carey JH, Herbert A, Hansen PD. DNA alkaline unwinding assay for monitoring the impact of environmental genotoxins. Environ Toxicol Water Qual 1996;11:351-4.

Reitman S, Frankel S. A colorimetric method for the determination of serum glutamic-oxalacetic and glutamic transaminases. J Clin Pathol 1957;28:56-63.

Rice DW, Seltenrich CP, Keller ML, Spies RB, Felton S. Mixed-function oxidase-specific activity in wild and caged Speckled Sanddabs Citharichthys stigmaeus in Elkhorn Slough, Moss Landing Harbour and Nearshore Monterey Bay, California. Environ Pol 1994;84:179-88.

Santos MA, Pacheco M. Anguilla anguilla L. stress biomarkers recovery in clean water and secondary-treated pulp mill effluent. Ecotoxicol Environ Saf 1996;35:96-100.

Santos MA, Pires F, Hall A. Metabolic effects of kraft mill effluents on the eel Anguilla anguilla L. Ecotoxicol Environ Saf 1990;20:10-9.

Schmid W. The micronucleus test for cytogenetic analysis. In: Hollaender A, editor. Chemical mutagenesis, vol. 4. New York: Plenum; 1976.

Shugart LR Molecular markers to toxic agents. In: Newman MC, Jagoe $\mathrm{CH}$, editors. Ecotoxicology - a hierarchical treatment. Boca Raton: Lewis Publishers, CRC Press; 1996. p. 133-61.

Shugart LR, Bickham J, Jackim G, McMahon G, Ridley W, Stein J, et al. DNA alterations. In: Huggett RJ, Kimerle RA, Mehrle PM, Bergman HL, editors. Biomarkers: biochemical, physiological and histological markers of anthropogenic stress. Chelsea (MI): Lewis Publishers; 1992. p. $125-53$.

Smith IR. Erythrocytic micronuclei in wild fish from Lakes Superior and Ontario that have pollution-associated neoplasia. J Great Lakes Res 1990;16(1):139-42.

Stegeman JJ, Lech JJ. Cytochrome P450 monooxygenase systems in aquatic species: carcinogen metabolism and biomarkers for carcinogen and pollutant exposure. Environ Health Perspect 1991;90:101-9.

Stegeman JJ, Hahn ME. Biochemistry and molecular biology of monooxygenases. In: Malins DC, Ostrander, GK, editors. Aquatic toxicology: molecular, biochemical, and cellular perspectives. NW, USA: Lewis/ CRC Press; 1994. p. 87-206.

Stein JE, Reichert WL, Nishimoto M, Varanassi U. Overview of studies on liver carcinogenesis in English sole from Puget Sound; evidence for a xenobiotic chemical etiology: II. Biochemical studies. Sci Total Environ 1990;94:51-69.

Tuvikene A, Huuskonen S, Koponen K, Ritola O, Mauer O, LindströmSeppä P. Oil shale processing as a source of aquatic pollution: monitoring of the biologic effects in caged and feral freshwater fish. Environ Health Perspect 1999;107(9):745-52.

Viarengo A, Bettella E, Fabbri R, Burlando B, Lafaurie M. Heavy metal 
inhibition of EROD activity in liver microsomes from the bass Dicentrarchus labrax exposed to organic xenobiotics: role of GSH in the reduction of heavy metal effects. Mar Environ Res 1997;44(1):1-11.

White PA. The genotoxicity of priority polycyclic aromatic hydrocarbons in complex mixtures. Mutat Res 2002;515(1-2):85-98.
Zoll-Moreaux C, Ferrier V. The Jaylet test (Newt Micronucleus Test) and the micronucleus test in Xenopus: two in vivo tests on amphibia evaluation of the genotoxicity of five environmental pollutants and of five effluents. Water Res 1999;33(19):2301-14. 